\title{
$\mathrm{X}$ 대역 액정 기반 능동형 반사 배열 안테나 설계 및 제작
}

\section{Design and Implementation of an X-Band Liquid-Crystal-Based Active Reflectarray Antenna}

\author{
김 호 겸·김 종 영*·오 정 석 \\ Ho-Gyeom Kim · Jong-Yeong Kim* · Jung-Suek Oh
}

요 약

$\mathrm{X}$ 대역에서 동작하는 액정 기반 반사 배열 안테나 설계 및 제작 결과를 기술하였다. 효율 파라미터의 정의 및 최적화 를 통해 고효율 반사 배열 안테나를 설계하였다. 액정의 높은 손실 정접을 고려하여 손실이 높은 물질 기반의 반사 배열 단위 셀을 모델링하여 단위 셀의 반사 손실을 최소화하였다. 또한 $2 \times 2$ 패치 배열 안테나를 사용함으로써 원하는 빔 패턴 을 갖는 급전 안테나를 설계하여 Spill over 효율과 Taper 효율을 최적화하였다. 차단 손실을 줄이기 위해 offset 급전 방식 으로 반사 배열 안테나를 설계 및 제작하여 브로드사이드 방향으로 $26 \%$ 의 개구면 효율을 확인하였다. DC 전압을 인가 하여 측정한 빔 패턴을 시뮬레이션 결과와 비교함으로써 몇 가지 빔 패턴에 대해서 유전율을 유추하였다.

\section{Abstract}

The fabrication and design of a liquid crystal (LC)-based X-band reflectarray antenna are described. A high-efficiency reflectarray antenna was achieved by defining and optimizing its efficiency parameters. Considering the high loss tangent of the LC, the equivalent circuit of the lossy medium was modeled, and the reflection loss of the unit cell was minimized. Furthermore, a $2 \times 2$ patch array antenna was employed to optimize the spillover and taper efficiency. To minimize blockage loss, the reflectarray was designed by employing offset feeding, resulting in an aperture efficiency of $26 \%$ in the broadside direction. Measured beam patterns were obtained by changing the applied bias voltage, and the simulated results were obtained by changing the permittivity of the LC. Consequently, the permittivity of the LC was determined by comparing the measured and simulated results.

Key words: Liquid Crystal, Refectlarray Antenna, Active Reflectarray, High Efficiency, Reconfigurable Reflectarray

$$
\text { I. 서 론 }
$$

반사 배열 안테나란 다수의 반사 소자들이 배열 형태
로 존재하는 안테나이다. 각 반사 소자의 정해진 반사 위 상에 의해 급전되는 전파의 위상을 재구성하여 원하는 형태의 방사 패턴을 얻을 수 있다. 이러한 반사 소자의 형

「본 연구는 국방과학연구소 미래도전기술 사업의 한화시스템(주) 시제개발비 지원으로 수행되었습니다.」 서울대학교 전기 - 정보공학부(Department of Electrical and Computer Engineering, Seoul National University) *한화 시스템 특수 레이다 팀(Specific Radar Team, Hanwha Systems)

• Manuscript received July 5, 2021 ; Revised July 15, 2021 ; Accepted October 6, 2021. (ID No. 20210705-056)

· Corresponding Author: Jung-Suek Oh (e-mail: jungsuek@snu.ac.kr) 
태나 크기는 원하는 반사 위상에 따라 정해지게 된다. 반 사 배열 안테나는 제작이 용이하며, 도파관 형태의 안테 나에 비해 가볍다는 장점이 있다. 그러나 이러한 반사 배 열 안테나는 입사되는 파면(wavefront)에 따라 한 가지 빔 성형만 가능하기 때문에 빔 스캐닝이 요구되는 통신 시 스템에서는 사용하기 어렵다. 최근 능동 소자를 활용하여 반사 배열 안테나의 다중 빔 포밍 기능을 구현하는 연구 들이 진행되고 있다 ${ }^{[1]-[3]}$. 능동 소자들을 활용한 반사 배 열 안테나들은 능동 소자들에 낮은 주파수의 $\mathrm{AC}$ 혹은 $\mathrm{DC}$ 전압/전류를 인가했을 때 각 소자의 위상이 변하게 되고, 이를 통해 원하는 빔을 형성할 수 있게 한다. PIN 다이오드는 전류 제어를 통해 안테나 다중 기능을 구현 하는 소자로 열이 많이 발생하며, 동작 시 on/off 상태만 존재하기 때문에 비트 제어를 한다는 단점이 있으나, 저 렴하고 구현이 용이하다는 장점이 있다. 버랙터 다이오드 기반 반사 배열 안테나는 버랙터에 인가되는 전압에 따 라 공핍층의 크기 변화에 따른 커패시턴스를 활용하여 동작을 하기 때문에 PIN 다이오드와 비교했을 때 비교적 연속적인 위상 제어가 가능하지만 높은 주파수에서 사용 이 어렵다는 단점이 있다. 액정을 활용한 반사 배열 안테 나는 전압에 따라 변화하는 액정의 분자의 배향이 달라 지며 커패시턴스의 변화가 생긴다. 따라서 액정 기반 반 사 배열 안테나는 버랙터 다이오드 기반의 반사 배열 안 테나와 마찬가지로 연속적인 제어가 가능하다. 액정은 또 한 앞선 PIN, 버랙터 다이오드처럼 반사 배열 안테나 표 면에 존재하는 것이 아니라, 액체 형태로 존재하기 때문 에 내부에 가둬지게 된다. 이는 기계적 안정성을 보장해 주지만 공정에 어려움을 증가시키는 원인이 되게 한다. 표 1은 세 가지 능동 소자들의 여러 가지 요인들을 비교 한 표이다. 액정 기반 반사 배열 안테나는 높은 주파수에

표 1. 능동 소자들의 성능 비교

Table 1. Comparison of the performance of active components.

\begin{tabular}{|c|c|c|c|c|}
\hline & Cost & $\begin{array}{c}\text { Power } \\
\text { consumption }\end{array}$ & RF loss & $\begin{array}{c}\text { Control } \\
\text { continuity }\end{array}$ \\
\hline PIN & Low & High & Low & $\times$ \\
\hline Varactor & High & Low & Mid & 0 \\
\hline LC & Mid & Low & High & 0 \\
\hline
\end{tabular}

서 설계가 용이하다. 그 이유는 액정의 물리적인 두께는 앏을수록 응답 속도가 빨라지며, 이러한 형태의 안테나는 주파수가 높을수록 구현이 용이하기 때문이다. 또한 액정 의 전기적인 두께가 증가할수록 반사 손실이 줄기 때문 에 이 또한 주파수가 높을수록 구현이 용이하다 ${ }^{[4]}$.

표 1 에서 액정의 $\mathrm{RF}$ 손실이 높은 이유는 액정의 손실 탄젠트(loss tangent)가 높기 때문이다. 이러한 이유로 현 재까지 보고된 $\mathrm{X}$ 대역에서 동작하는 액정 기반 반사 배 열 안테나의 단위 셀은 높은 반사 손실을 보이며 높은 효 율로 구현된 구조가 보고되지 않았다다. 본 논문에서는 26 $\%$ 의 안테나 개구면 효율을 가지는 액정 기반 반사 배열 안테나를 제시한다. 이를 위해 낮은 손실의 단위 셀을 설 계하고, 반사 배열 안테나의 최적 효율을 구하기 위한 과 정을 보인다. 또한 제작된 샘플을 시뮬레이션과의 비교를 통해 공정 신뢰도를 확보한다.

본 논문은 다음과 같은 구성으로 작성되어진다. 2, 3장 에서는 반사 배열 안테나의 효율 파라미터를 분석하고 액정 기반 단위 셀과 급전 안테나 설계, 그리고 반사 배열 안테나의 설계를 기술한다. 4장에서는 제작된 반사 배열 안테나 샘플의 측정 및 시뮬레이션 비교를 기술하고, 5 장 에서 결론을 맺는다.

\section{II. 반사 배열 안테나 효율 파라미터}

반사 배열 안테나 설계 시 개구면 효율 $\eta_{a}$ 은 식 (1)과 같이 표현된다 ${ }^{[6]}$.

$\eta_{a}=\eta_{\text {ref }} \cdot \eta_{\text {phase }} \cdot \eta_{\text {spill }} \cdot \eta_{\text {taper }} \cdot \eta_{\text {edge }} \cdot \eta_{\text {pol }} \cdot \eta_{\text {block }} \cdot \eta_{\text {etc }}$

$\eta_{r e f}$ 와 $\eta_{\text {phase }}$ 효율은 각각 단위 셀들의 반사 손실과 반 사 위상에 관련된 효율이다. 단위 셀의 반사 손실을 최대 한 줄이고, 바이어스 전압 크기에 따른 반사 위상의 범위 를 늘리면 증가한다. $\eta_{\text {spill }}$ 와 $\eta_{\text {taper }}$ 효율은 각각 급전 안테 나로부터 오는 전파의 전력량, 균일성에 관련된 효율이 다. Spill, Taper 효율은 급전 안테나 설계 시 중요한 파라 미터이며, 서로 Trade-off의 관계를 보이기 때문에 적절한 타협이 필요하다. $\eta_{e d g e}$ 효율은 개구면 가장자리에서 굴절 되어 방사하는 전파에 의한 손실에 대한 효율이다. 급전 
안테나 최적화 설계를 하게 될 경우, edge 효율도 $90 \%$ 이상의 효율이 되기 때문에 따로 최적화를 진행하진 않 는다. $\eta_{p o l}$ 효율은 방사되는 전파의 편파가 얼마나 동일 편 파(co-polarization)로 방사하는지에 대한 효율이다. 액정 기반 반사 배열 안테나는 주로 단일 편파로 동작하기 때 문에 편파 효율이 높은 편이다. $\eta_{b l o c k}$ 효율은 급전 안테나 에 의해 반사 배열에서 방사되는 전파가 일부 차단되어 발생하는 손실에 대한 효율이다. 차단 효율은 급전 안테 나의 급전 위치에 따라 달라지기 때문에, 높은 효율의 반 사 배열 안테나 설계를 위해서는 최적화 과정이 필요한 효율 파라미터이다. 마지막으로 $\eta_{e t c}$ 효율은 공정 오차, 양 자화 에러, 단위 셀 상호 결합에 의한 손실 등을 표현하는 효율이다.

\section{III. 액정 기반 반사 배열 안테나 설계}

\section{3-1 액정 기반 단위 셀 설계}

그림 1(a)는 액정 기반 반사 배열 단위 셀의 일반적인 개념도를 보여준다. 액정은 액체 상태로 존재하기 때문에 이를 가둘 수 있는 유전체 3 개가 필요하다. 상부와 하부 기판의 하/상 측에 존재하는 금속은 액정의 분자들을 배

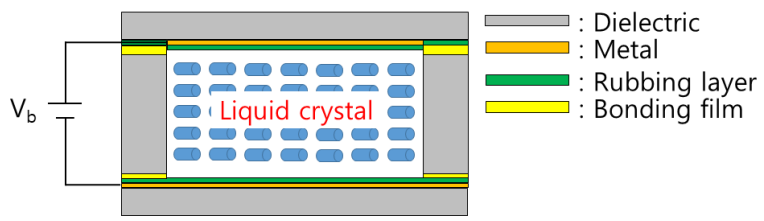

(a) 액정 기반 반사 배열 단위 셀 기본 개념도

(a) Fundamental structure of the LC-based refelctarray unit cell

\begin{tabular}{|c|c|c|c|}
\hline $\begin{array}{c}\text { Bias voltage } \\
\left(\mathrm{V}_{\mathrm{b}}\right)\end{array}$ & 0 & $\begin{array}{c}\mathrm{V}_{\mathrm{b}} \\
\left(0<\mathrm{V}_{\mathrm{b}}<\mathrm{V}_{\text {max }}\right)\end{array}$ & $\mathrm{V}_{\text {max }}$ \\
\hline Permittivity & $\varepsilon_{\perp}$ & $\begin{array}{c}\varepsilon_{\mathrm{b}} \\
\left(\varepsilon_{\perp}<\varepsilon_{\mathrm{b}}<\varepsilon_{\|}\right)\end{array}$ & $\varepsilon_{\|}$ \\
\hline $\begin{array}{c}\text { Dipole } \\
\text { alignment }\end{array}$ & $\wp$ & & $\mathrm{O}$ \\
\hline
\end{tabular}

(b) 바이어스 전압에 따른 유전율 및 분자 배향

(b) Permittivity and direction of the dipole versus bias voltage

그림 1. 액정 기반 반사 배열 단위 셀 기본 개념도

Fig. 1. Fundamental structure of the LC-based reflectarray unit cell.
향시킬 수 있는 전계가 발생하도록 하는 역할을 하며, 배 향막은 액정의 초기 분자 배향을 위해 존재하며 이는 바 이어스 전압을 인가하지 않았을 때의 유전율을 나타내게 된다. 각각의 유전체들은 본딩 필름에 의해 접합된다. 그 림 1(b)는 바이어스 전압을 인가하였을 때 바뀌는 분자의 배향과 그에 따른 유전율을 보여준다. 그림 1(a)처럼 바이 어스 전압 $\mathrm{V}_{\mathrm{b}}$ 인가 시 전계가 분자들에 수직한 방향으로 발생을 하게 되고, 전계와 분자가 이루고 있는 각도에 비 례하는 토크가 발생하여 최종적으로 전계와 수평한 방향 으로 분자들이 배향하게 된다. 이때 전압 크기에 따라 배 향 정도가 달라져 연속적인 유전율을 얻을 수가 있다.

종래의 보고된 문헌들에서 액정 기반 반사 배열 단위 셀들은 반사 손실이 높은 편이다. 그 이유는 액정의 손실 탄젠트가 높기 때문에 손실이 높은 유전체로 모델링이 되기 때문이다. 그림 2 는 그림 1 의 단위 셀의 무한 주기 구조로 해석 시 상호 결합(mutual coupling)을 고려하지 않 은 기본적인 액정 기반 반사 배열 단위 셀 구조 및 회로 도를 보여준다. 하부 기판은 그라운드에 의해 모델링 되 지 않는다. 액정은 grounded dielectric으로 모델링되어 특 성 임피던스 $\mathrm{Z}_{\mathrm{LC}}$ 를 갖는 전송선으로 표현된다. 또한 $\mathrm{LC}$ 상부에 맞닿아 있는 금속은 여러 형태를 가질 수 있지만 일반적으로 사각 형태로 구성된다. 상부 기판은 저손실 유전체를 사용할 경우, 저손실 전송선으로 모델링되며, 두께에 따라서 $\mathrm{L}$ 혹은 병렬 $\mathrm{L}, \mathrm{C}$ 로 표현된다. 사각 형태의 금속은 직렬 커패시턴스와 인덕터로 모델링되며, $\mathrm{LC}$ 의 복소 유전율에 의해 저항 성분이 고려된다 ${ }^{[4]}$. 저항 성분

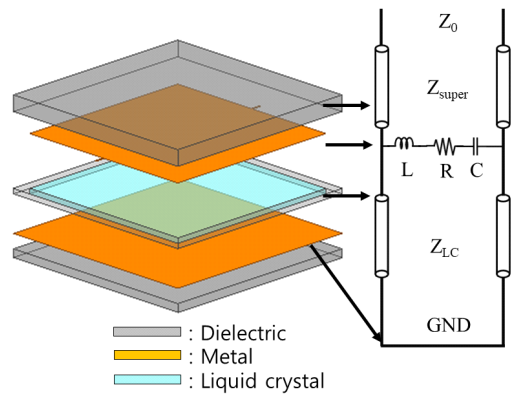

그림 2. 기본적인 액정 기반 반사 배열 단위 셀 구조 및 회로도

Fig. 2. Exploded view and corresponding equivalent circuit of the conventional LC-based reflectarray unit cell. 
은 계산의 편의상 직렬 성분으로 표현된다. 그림 2 의 회 로도에서 반사 손실을 줄일 수 있는 방안은 손실 탄젠트 값을 낮추거나 상부 기판 혹은 액정의 두께가 증가해야 한다.

상부 기판 혹은 액정의 두께를 증가시키는 방안은 또 다른 문제를 야기하는데, 액정의 두께가 증가할수록 액정 의 반응 속도가 두께의 제곱에 비례하여 느려진다. 또한 그림 2와 같은 기본적인 액정 기반 단위 셀은 상부 기판 을 늘려도 반사 손실이 큰 폭으로 감소하지 않는다. 상부 기판의 두께 증가는 $Z_{\text {super }}$ 의 인덕턴스를 증가시키게 되는 데, 이는 단위 셀 입력 임피던스의 허수부에만 영향을 주 기 때문에 반사 손실을 크게 개선시킬 수 없다.

그림 3은 본 논문에서 제안하는 단위 셀을 보여준다. 상부 기판에 금속 패치가 추가되었으며, 금속 비아를 통 해 금속 패치들이 연결된다. 하부 기판 또한 용이한 바이 어스를 위해 금속 비아를 통해 하부 기판 상/하부에 그라 운드 금속이 존재한다. 추가된 금속 패치는 커패시터, 금 속 비아는 인덕터로 모델링되며, 두 파라미터에 의해 입 력 임피던스가 달라지고, 금속 비아의 지름 혹은 상부 기 판의 두께를 변화시키며, 반사 손실을 최적화할 수 있다[7].

표 2는 본 논문에서 반사 배열 설계에 사용된 단위 셀들 의 물리적 변수 정보를 나타낸다. 단위 셀 크기는 $10 \mathrm{~mm}$, 최대 반사 손실은 $0.82 \mathrm{~dB}$, 위상 변화 범위는 $300^{\circ}$ 이다.

그림 4(a)는 액정 기반 반사 배열 단위 셀의 기본적인 구조와 제안하는 구조와의 반사 손실을 비교한다. 상부

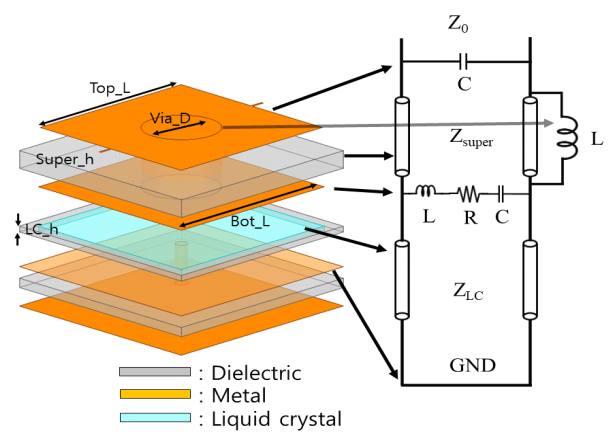

그림 3. 제안하는 액정 기반 반사 배열 단위 셀 구조 및 회로도

Fig. 3. Exploded view and corresponding equivalent circuit of the proposed LC-based reflectarray unit cell.
표 2. 설계된 단위 셀 성능 및 크기

Table 2. Specification and size of the designed unit cell.

\begin{tabular}{|c|c|c|c|c|c|c|c|}
\hline & $\begin{array}{c}\text { Vid_ } \\
\text { D } \\
(\mathrm{mm})\end{array}$ & $\begin{array}{c}\text { Top_ } \\
\mathrm{L} \\
(\mathrm{mm})\end{array}$ & $\begin{array}{c}\text { Super__ } \\
\mathrm{h} \\
(\mathrm{mm})\end{array}$ & $\begin{array}{c}\text { Bot__ } \\
\mathrm{L}\end{array}$ & $\begin{array}{c}\mathrm{LC} \mathrm{h} \\
(\mathrm{mm})\end{array}$ & $\begin{array}{c}\text { Reflection } \\
\text { loss } \\
(\mathrm{dB})\end{array}$ & $\begin{array}{c}\text { Reflection } \\
\text { phase } \\
\left({ }^{\circ}\right)\end{array}$ \\
\hline UC1 & 0.5 & 8.7 & 0.76 & 7.5 & 0.25 & 0.26 & 140 \\
\hline UC2 & 0.5 & 9 & 0.76 & 7.5 & 0.25 & 0.43 & 120 \\
\hline UC3 & 0.5 & 9.2 & 0.76 & 7.5 & 0.25 & 0.8 & 90 \\
\hline UC4 & 0.5 & 9.3 & 0.76 & 7.5 & 0.25 & 0.82 & -20 \\
\hline UC5 & 0.5 & 9.4 & 0.76 & 7.5 & 0.25 & 0.76 & -70 \\
\hline UC6 & 0.5 & 9.5 & 0.76 & 7.5 & 0.25 & 0.51 & -100 \\
\hline UC7 & 0.5 & 9.6 & 0.76 & 7.5 & 0.25 & 0.32 & -130 \\
\hline UC8 & 0.5 & 9.7 & 0.76 & 7.5 & 0.25 & 0.21 & -160 \\
\hline
\end{tabular}

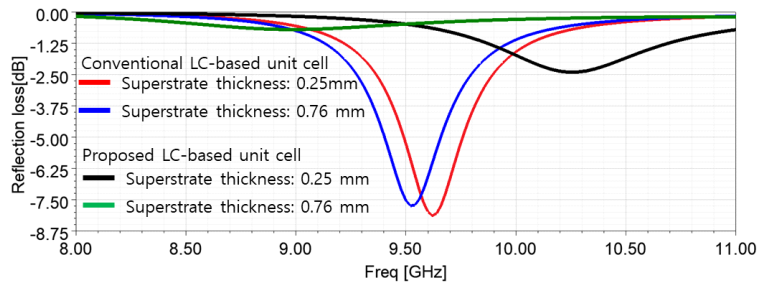

(a) 기존 단위 셀과 제안하는 단위 셀 반사 손실 비교

(a) Comparison of the reflection loss between conventional and proposed unit cell

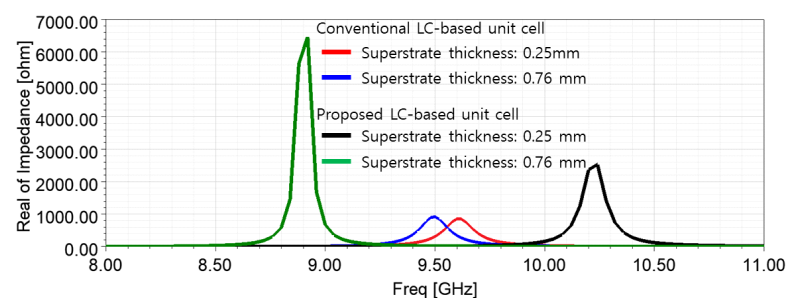

(b) 기존 단위 셀과 제안하는 단위 셀 임피던스 실수부 비교

(b) Comparison of the real impedance between conventional and proposed unit cell

그림 4. 기존 단위 셀과 제안하는 성능 비교

Fig. 4. Performance comparison between the conventional and proposed unit cell.

유전체와 스페이서(액정) 유전체는 Taconic TLY5 기판으 로 설계를 하였으며, 하부 기판은 FR4를 사용하였다. 사 용된 액정의 가변 유전율은 2.4에서 3.5 이며, 손실 탄젠트 는 0.012 에서 0.0064 이다. 상용 기판의 두께를 고려하여 
상부 기판의 두께의 변화를 주었을 때 제안하는 구조는 반사 손실 및 공진 주파수가 대폭 감소하였으며, 그림 4(b)를 통해서 명확하게 확인이 가능하다.

\section{3-2 급전 안테나 설계}

급전 안테나에서 방사하는 정규화된 전계는 식 (2)와 같이 코사인 함수로 표현이 가능하다 ${ }^{[8]}$.

$$
E_{\text {feed }} \propto \cos ^{q} \theta
$$

$q$ 가 높을수록 안테나의 지향성이 높아지고, 그에 따라 반 전력 빔 폭이 좁아진다. 반 전력 빔 폭(HPBW)에 따라 서 최적의 급전 효율(spill over×taper)을 얻을 수 있다 ${ }^{[8]}$.

반 전력 빔 폭에 따라서 최적의 spill over, taper 효율의 곱을 얻을 수 있다. 그림 5는 최적의 급전 효율(spill× taper)을 위한 최적화 파라미터를 보여준다. $F$ 와 $D$ 는 각각 급전 안테나와 반사 배열 사이인 초점거리, 반사 배열의 크기를 의미한다. 그림 $6(\mathrm{a})$ 는 $q$ 값에 따라 안테나의 지향 성 및 $\mathrm{HPBW}$ 가 어떤 식으로 변화하는지 보여준다.

급전 안테나를 선정한 뒤 해당하는 $q$ 값을 계산하게 되 면 그림 6(b)와 같이 $\theta_{\mathrm{sub}}$ 가 결정되며, 반사 배열의 크기 $D$ 가 정해진다면 초점거리 $F$ 를 구할 수가 있다. 급전 안테 나 선정 시 고려사항은 여러 가지가 있다. 급전 안테나의 이득이 높을수록 초점거리가 멀어지기 때문에 반사 배열 안테나의 높이를 줄이고 싶을 경우에는 낮은 이득의 급 전 안테나를 사용해야 한다. 또한 안테나의 크기가 클 경 우, 차단 손실이 크기 때문에 차단 손실을 피하기 위해선 급전 안테나를 기울여 급전을 하거나 크기가 작은 안테

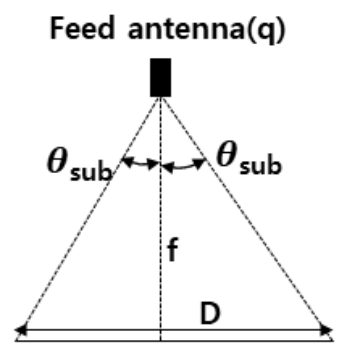

그림 5. 급전 효율 (spill×taper) 최적화 파라미터

Fig. 5. Optimization parameters of the feed efficiency (spill $\times$ taper).

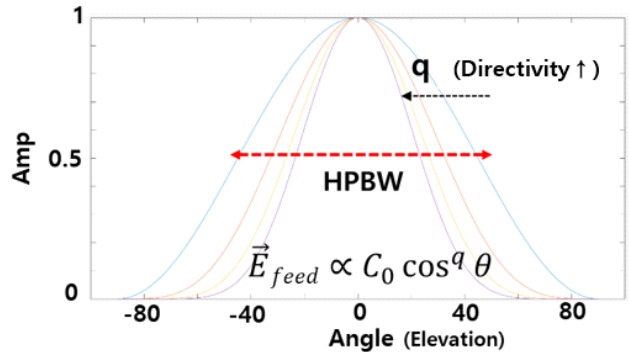

(a) $q$ 값에 따른 반 전력 빔 폭 (HPBW)

(a) Half power beam width versus the $q$ value

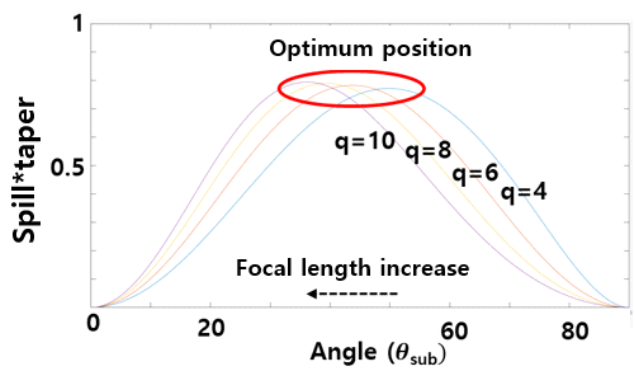

(b) $q$ 값에 따른 급전 효율

(b) Feed efficiency versus the $q$ value

그림 6. 급전 효율 최적화 방안

Fig. 6. Optimization method of the feed efficiency.

나를 선정해야 한다. 안테나의 이득이 작을 경우, 보상해 야할 위상의 기울기가 가팔라져 위상 보상 시 단위 셀 간 의 불연속에 의한 상호 결합이 일어나 위상 효율이 떨어 진다. 본 논문에서는 $2 \times 2$ 패치 배열 안테나를 급전 안테 나로 사용한다. $2 \times 2$ 패치 배열 안테나의 장점은 혼 안테 나에 비해 차단 손실이 낮아 차단 효율이 높으며, 소자 간 격을 조정함으로써 빔 폭 조정이 가능하다.

그림 7은 설계된 급전 안테나와 정규화된 빔 패턴을 보 여준다. 사이드 로브를 억제하기 위해 동축 케이블 급전 방식을 사용하였다. 반 전력 빔 폭은 45 도이며, 이에 해당 하는 $q$ 값은 2.9 이다. 설계하고자 하는 반사 배열의 크기 는 $120 \mathrm{~mm} \times 120 \mathrm{~mm}(12 \times 12$ 개)로 설정한 뒤 최적의 초점 거리를 계산하면 $6 \mathrm{~cm}$ 가 된다.

\section{3-3 액정 기반 반사 배열 안테나 설계}

설계된 단위 셀과 급전 안테나를 기반으로 반사 배열 을 설계한다. 차단 손실을 고려하여 Off-axis 급전 방식으 


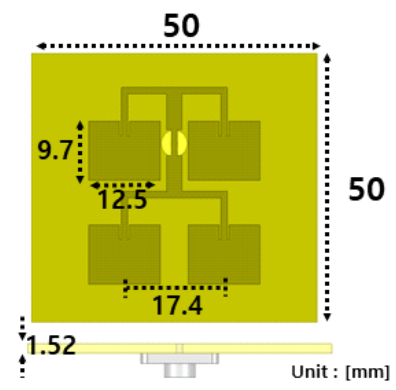

(a) 설계된 $2 \times 2$ 패치 배열 안테나 구조

(a) Designed $2 \times 2$ patch array feed antenna

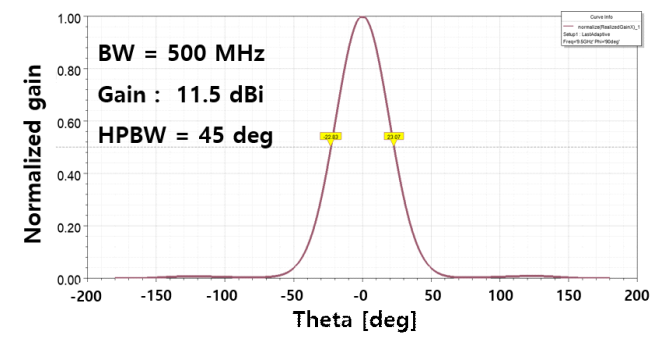

(b) 정규화된 안테나 빔 패턴

(b) Normalized beam pattern

그림 7. 설계된 급전 안테나와 정규화된 빔 패턴

Fig. 7. Designed $2 \times 2$ patch array feed antenna and corresponding normalized beam pattern.

로 설계를 진행하였다. 급전 각도를 주게 되면 그에 따라 spill over 효율과 taper 효율이 달라진다. 그림 6의 계산 방 식은 급전 각도에 대한 계산이 어려우며, 안테나 부엽에 의해 실제 최적의 초점거리와 달라질 수 있다. 본 논문에 서는 full-wave 시뮬레이터의 field calculator 및 식 (3), 식 (4)를 통해 급전 각도, 초점 거리를 바꾸어 가며 최적의 급전 효율을 계산한다 ${ }^{[9]}$.

$$
\begin{gathered}
\eta_{\text {spill }}=\frac{\iint_{A} \vec{P}(\vec{r}) \cdot \overrightarrow{d s}}{\iint_{\sigma} \vec{P}(\vec{r}) \cdot \overrightarrow{d s}} \\
\eta_{\text {taper }}=\frac{1}{A} \frac{\left|\iint_{A} I(x, y) d A\right|^{2}}{\iint_{A}|I(x, y)|^{2} d A}
\end{gathered}
$$

$\mathrm{A}$ 는 반사 배열의 개구면, $\sigma$ 는 급전 안테나를 감싸는 가상의 반구면이다. Spill over 효율은 식 (3)과 같이 반사
배열에 도달하는 포인팅 벡터를 면적분하여 입사되는 전 력량을 급전 안테나에서 나오는 전력량으로 나누어 준 값을 통해 계산한다. Taper 효율은 식 (4)와 같이 표현되 며, $I(x, y)$ 는 전계의 세기를 의미한다. 식 (4)에 나타난 바 와 같이 taper 효율은 개구면에 걸쳐 전계가 얼마나 균일 한지를 나타낸다. Offset 각도를 주게 되면 단위 셀의 편 파 응답도 달라지므로 함께 고려를 해야 한다. 계산을 통 해 얻은 최적의 offset 각도는 30 도, 초점거리는 $6 \mathrm{~cm}$ 이다. 그림 8은 full-wave simulator의 field calculator로 계산된 spill, taper 그리고 급전 효율 계산 결과를 보여준다. 그림 9는 최적 급전 각도 및 초점거리에서의 위상 분포를 보여 주며, 위상 분포에 따라 Zone을 나누게 되며, 해당하는 번 호의 다른 위상 응답을 나타내는 단위 셀들이 배치된다. 본 논문에서는 브로드사이드 방향으로 방사를 하는 반사 배열 안테나를 설계하였다. 그림 10 은 설계된 액정 기반 반사 배열을 보여준다. 단위 셀의 크기는 $10 \mathrm{~mm}$ 이며, 총

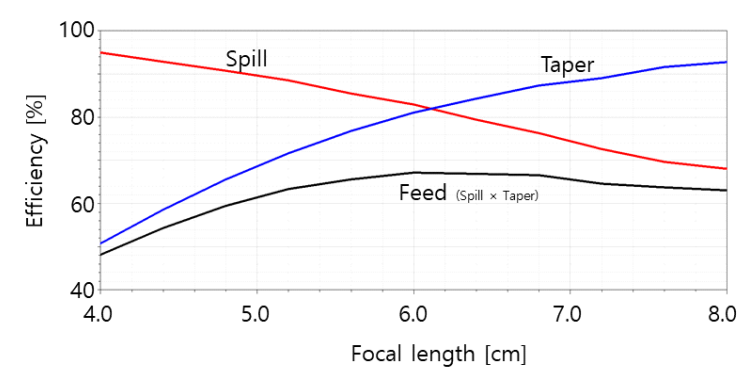

그림 8. 급전 안테나와 반사 배열 배치도

Fig. 8. Configuration of the feed antenna and the reflectarray.

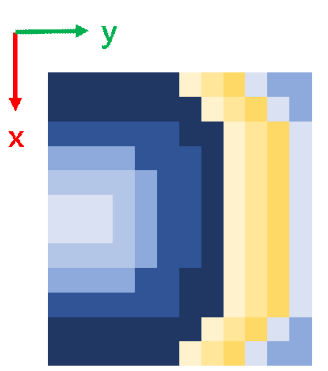

Zone 1

Zone 2

Zone 3

Zone 4

Zone 5

Zone 6

Zone 7

Zone 8

그림 9. 개구면 위상 분포도

Fig. 9. Phase distribution on the aperture of the reflectarray. 
THE JOURNAL OF KOREAN INSTITUTE OF ELECTROMAGNETIC ENGINEERING AND SCIENCE. vol. 32, no. 10, October. 2021.

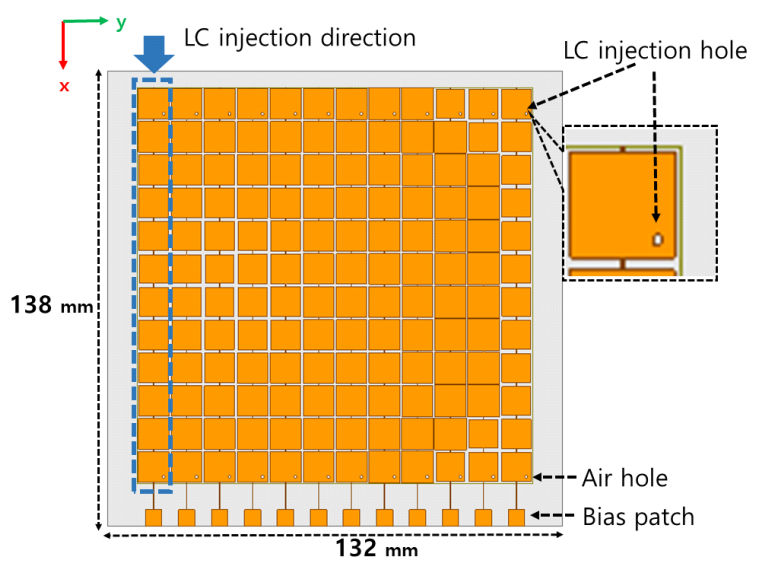

그림 10. 액정 기반 반사 배열 상면도

Fig. 10. Top view of the LC-based reflectarray.

12 개 $\times 12$ 개의 단위 셀로 구성되어 있다. 방사 개구면으로 부터 $4 \mathrm{~mm}$ 떨어진 지점에 있는 바이어스 패치는 액정의 열별 제어를 위해 존재한다. 액정의 주입은 열 단위로 주 입된다(파란색 화살표 방향). 각 역에 존재하는 액정 주입 구로 액정을 주입 후 내부 공기는 공기 배출구로 배출되 며, 내부는 액정으로 채워진다. 바이어스 패치를 통해 DC 서플라이와 연결되며, 액정에 바이어스를 인가한다.

그림 11은 설계된 액정 기반 반사 배열 안테나의 빔 패 턴 시뮬레이션 결과를 보여준다. 주파수는 $9.35 \mathrm{GHz}$ 에서 의 결과이며, 이득은 $17.1 \mathrm{dBi}$ 이고, 부엽 준위는 $-10 \mathrm{~dB}$ 이다. 개구면 효율은 $29.1 \%$ 이며, 각각의 효율 버짓은 표 3 에 명시되어 있다. 효율 버짓들의 곱은 $30 \%$ 로 개구면

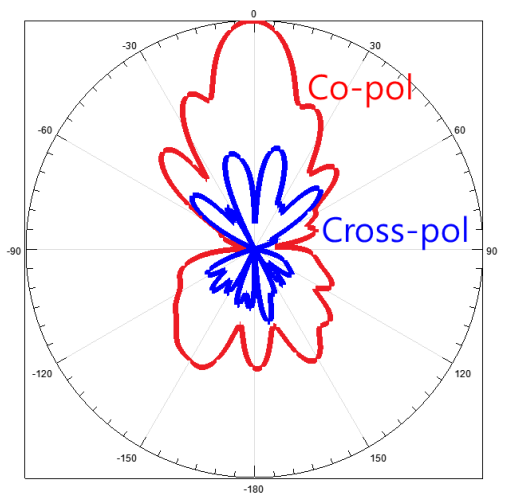

그림 11. $9.35 \mathrm{GHz}$ 에서의 빔 패턴 시뮬레이션 결과 Fig. 11. Simulation results of beam pattern at $9.35 \mathrm{GHz}$.
표 3. 설계된 액정 기반 반사 배열 안테나 효율 버짓

Table 3. Efficiency budgets of the LC-based reflectarray antenna.

\begin{tabular}{|c|c|}
\hline Efficiency budget & $\%$ \\
\hline Spill over & 82.0 \\
\hline Taper & 83.0 \\
\hline Polarization & 90.0 \\
\hline Reflection & 90.0 \\
\hline Phase & 85.0 \\
\hline Edge & 90.0 \\
\hline Blockage & 71.0 \\
\hline
\end{tabular}

효율과 상당히 유사한 값으로 계산되었으며, 나머지 효율 은 기타 효율로 분류된다. 기타 효율은 단위 셀 상호 결 합, 양자화 에러, 전파의 반사 시 반사 크기가 다르기 때 문에 생기는 전계 분포의 불평형 등이 있다.

\section{$\mathrm{IV}$. 액정 기반 반사 배열 안테나 제작 및 측정}

\section{4-1 액정 기반 반사 배열 안테나 제작}

그림 12 는 제작된 $2 \times 2$ 패치 배열 안테나와 측정한 빔 $2 \mathrm{D}$ 빔 패턴을 보여준다. 부착된 커넥터는 일반적인 SMA 커넥터를 사용하였다. 안테나에 사용된 기판은 Taconic

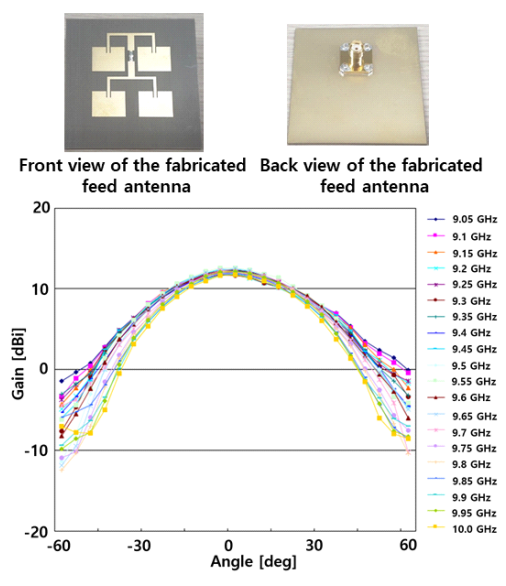

2D beam pattern measurement results of the feed antenna

그림 12. 제작된 급전 안테나 샘플 및 측정 결과

Fig. 12. Fabricated feed antenna sample and measurement results. 
TLY 5 를 사용하였으며, 두께는 $1.52 \mathrm{~mm}$ 이다. 주파수는 $9.05 \mathrm{GHz} \sim 10 \mathrm{GHz} 50 \mathrm{MHz}$ 단위로 측정하였으며, 타겟 주파수인 $9.35 \mathrm{GHz}$ 에서 이득은 $12.0 \mathrm{dBi}$, 반 전력 빔 폭은 47.0 도이다.

급전 안테나는 여러 주파수에서 큰 성능 차이를 보이 지 않는 것을 확인하였다. 수신 안테나로는 $15 \mathrm{dBi}$ 스탠 다드 혼 안테나를 사용하였다.

그림 13 은 제작된 구조와 액정 기반 반사 배열 안테나 의 측정 셋업 및 전압을 인가하지 않았을 때의 측정 결과 를 시뮬레이션 결과와 비교한다. 그림 12(a)에서 스페이 서 내부 빈 공간에 액정이 주입되게 된다. 그림 12(b) 내 에서의 빨간색 실선은 시뮬레이션 결과이며, 검은색 실선 은 측정 결과이다. $3 \mathrm{D}$ 프린터로 제작된 지지대를 이용하 여 급전 안테나와 반사 배열을 고정하였으며, 바이어스 패치에는 점퍼선을 이용해 $\mathrm{DC}$ 서플라이와 연결하여 원 하는 전압을 인가할 수 있게 하였다. 시뮬레이션 결과도 마찬가지로 지지대를 고려한 결과이다. 지지대의 재료는

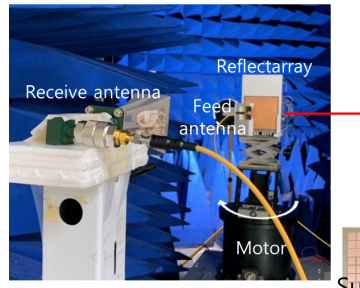

LC-based reflectarray

(a) 측정 셋업 및 제작된 액정 기반 반사 배열

(a) Measurement setup and fabricated LC-based reflectgarray

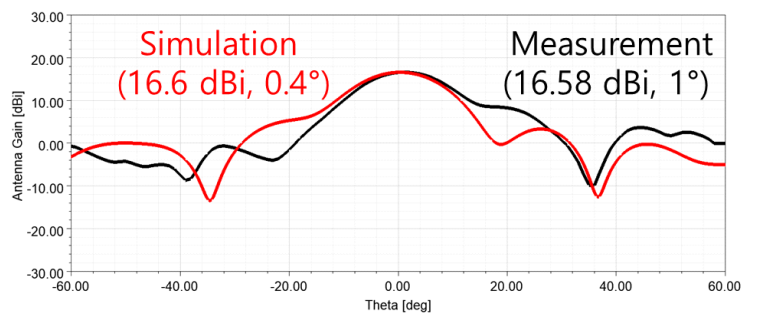

(b) 시뮬레이션과 측정 결과 비교

(b) Comparison between simulated and measured results

그림 13. 측정 셋업/제작 구조 및 측정 결과

Fig. 13. Measurement setup and measurement results.
PLA 재질의 필라멘트를 사용하였다. 지지대로 인해 이득 이 $0.5 \mathrm{~dB}$ 감소하였으며, 이로 인해 개구면 효율은 $26 \%$ 로 감소하였다. 측정된 부엽 준위는 $-12.1 \mathrm{~dB}$ 이다.

표 4는 대역별 액정 기반 반사 배열 안테나의 크기, 이 득, 효율, 부엽 준위, 그리고 빔 조향 축을 나타낸 표이다. $\mathrm{X}$ 대역에서 동작하는 액정 기반 반사 배열 안테나의 성 능이 기술되어 있는 논문은 없다. 액정 기반 안테나는 물 성의 특성상 주파수가 높을수록 성능이 향상되나, 본 논 문에서 설계한 액정 기반 반사 배열 안테나는 X 대역에 서도 브로드사이드 기준 높은 성능을 만족한다.

그림 14는 전압에 따른 빔 패턴 측정 및 시뮬레이션 결 과이다. 모든 셀에 동일한 전압을 인가하여 빔 패턴을 측 정하였으며, 유전율을 변경하며 얻은 시뮬레이션 결과와 의 비교를 통해 특정 전압에 해당하는 유전율을 구한다. 실선과 점선은 각각 시뮬레이션, 측정 결과를 보여준다.

표 4. 액정 기반 반사 배열 안테나들의 성능 비교 Table 4. Comparison of electrical performance of LC-based reflectarrays.

\begin{tabular}{|c|c|c|c|c|}
\hline Performance & {$[10]$} & {$[11]$} & {$[12]$} & This work \\
\hline Freq (GHz) & 10 & 78 & $96 \sim 102$ & 9.35 \\
\hline Max. gain (dBi) & - & 25.1 & 19.4 & 16.58 \\
\hline $\begin{array}{c}\text { Aperture } \\
\text { efficiency (\%) }\end{array}$ & - & 6.77 & 18.5 & 26 \\
\hline Steering axis & $1 \mathrm{D}$ & $1 \mathrm{D}$ & $1 \mathrm{D}$ & $1 \mathrm{D}$ \\
\hline SLL (dB) & - & -6 & -13 & -12.1 \\
\hline $\left.\begin{array}{c}\text { Dimension } \\
(\text { mm }\end{array}{ }^{2}\right)$ & $240 \times 240$ & $75 \times 75$ & $102 \times 102$ & $120 \times 120$ \\
\hline Polarization & LP & LP & LP & LP \\
\hline
\end{tabular}

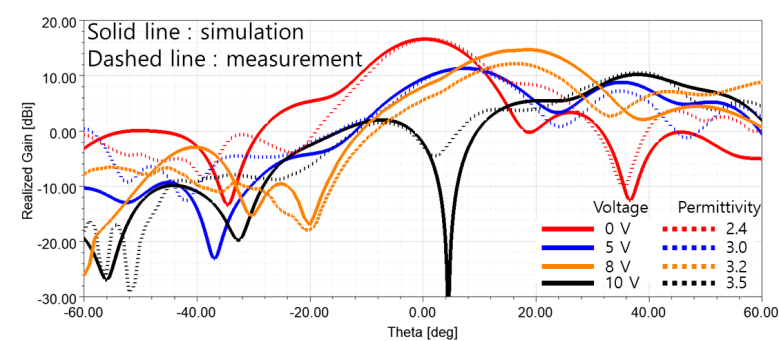

그림 14. 전압에 따른 시뮬레이션과 측정 결과 비교

Fig. 14. Comparison between simulated and measured results versus bias voltage. 
THE JOURNAL OF KOREAN INSTITUTE OF ELECTROMAGNETIC ENGINEERING AND SCIENCE. vol. 32, no. 10, October. 2021.

인가한 전압은 $0,5,8$ 그리고 $10 \mathrm{~V}$ 이다. $10 \mathrm{~V}$ 이상의 전 압을 인가했을 때에는 빔 패턴의 변화가 적어지는 것을 확인하였다. $5 \mathrm{~V}, 8 \mathrm{~V}$ 그리고 $10 \mathrm{~V}$ 에서의 측정 이득은 각 각 $11.3 \mathrm{dBi}, 12.12 \mathrm{dBi}$ 그리고 $10.45 \mathrm{dBi}$ 이다. 주 빔의 방 향은 7.4도, 17 도 그리고 37 도이다. 시뮬레이션 결과와 측 정된 결과 비교를 통해 공정에 대한 신뢰도를 확보할 수 있으며, 인가된 전압에 따른 유전율을 유추할 수 있다. 본 논문에서 설계된 반사 배열 안테나의 단위 셀들은 동일 한 셀들로 배치되어 있지 않기 때문에 모든 전압에 대한 빔 패턴 결과와 시뮬레이션 결과의 비교가 불가하며, 다 른 전압에 대한 빔 패턴 및 유전율을 예측하기 위해서는 유전율 스윕에 의한 빔 패턴 비교가 아닌 단위 셀을 이용 하여 $S$ 파라미터를 비교하거나 유전율을 측정할 수 있는 구조를 제작하여 비교를 하여 얻어야 한다.

향후 연구에서 전압에 따른 유전율을 분석한다면 원하 는 조향 각도에서도 높은 이득을 유지할 수 있는 구조를 설계할 수 있을 것이다.

\section{$\mathrm{V}$. 결 론}

본 논문에서는 X 대역 액정 기반 반사 배열 안테나를 설계 및 제작 검증을 통해 시뮬레이션 및 공정에 대한 신 뢰성을 확보하였다. 반사 배열 안테나의 효율 파라미터들 을 정의하였고, 각각의 효율들을 높일 수 있는 단위 셀, 급전 안테나를 설계하여 브로드사이드 기준 $26 \%$ 이상의 효율을 달성하였다. 타 문헌에 보고된 X 대역 액정 기반 반사 배열 안테나보다 많은 빔 조향 각도를 보여주며, 단 위 셀의 반사 손실이 적고 안테나 효율이 높다. 본 논문에 서 설계된 구조는 향후 X 대역뿐만 아니라, 여러 대역에 서도 높은 효율의 액정 기반 반사 배열 안테나를 설계할 수 있는 방향을 제시할 수 있을 것이다.

\section{References}

[1] J. Han, L. Li, G. Liu, Z. Wu, and Y. Shi, "A wideband 1 bit $12 \times 12$ reconfigurable beam-scanning reflectarray: Design, fabrication, and measurement," IEEE Antennas and Wireless Propagation Letters, vol. 18, no. 6, pp. 1268-1272, Jun. 2019.
[2] S. V. Hum, M. Okoniewski, and R. J. Davies, "Realizing an electronically tunable reflectarray using varactor diode-tuned elements," IEEE Microwave and Wireless Components Letters, vol. 15, no. 6, pp. 422-424, Jun. 2005.

[3] G. Perez-Palomino, P. Baine, R. Dickie, M. Bain, J. A. Encinar, and R. Cahill, et al., "Design and experimental validation of liquid crystal-based reconfigurable reflectarray elements with improved bandwidth in F-band," IEEE Transactions on Antennas and Propagation, vol. 61, no. 4, pp. 1704-1713, Apr. 2013.

[4] F. Costa, A. Monorchio, "Closed-form analysis of reflection losses in microstrip reflectarray antennas," IEEE Transactions on Antennas and Propagation, vol. 60, no. 10, pp. 4650-4660, Oct. 2012.

[5] W. Hu, M. Y. Ismail, R. Cahill, J. A. Encinar, V. F. Fusco, and H. S. Gamble, et al., "Liquid-crystal-based reflectarray antenna with electronically switchable monopulse patterns," Electronics Letters, vol. 43, no. 14, pp. 744-745, Jul. 2007.

[6] J. Nourinia, C. Ghobadi, B. Mohammadi, and F. Alizadeh, "Aperture efficiency study of square reflectarray antennas," Wireless Engineering and Technology, vol. 8, pp. 66-78, Jul. 2018.

[7] H. Kim, J. Kim, and J. Oh, "Liquid-crystal-based X-band reactively loaded reflectarray unit cell to reduce reflection loss," IEEE Antennas and Wireless Propagation Letters, vol. 20, no. 10, pp. 1898-1902, Oct. 2021.

[8] D. M. Pozar, S. D. Targonski, and H. D. Syrigos, "Design of millimeter wave microstrip reflectarrays," IEEE Transactions on Antennas and Propagation, vol. 45, no. 2, pp. 287-296, Feb. 1997.

[9] A. Yu, F. Yang, A. Z. Elsherbeni, J. Huang, and Y. Rahmat-Samii, "Aperture efficiency analysis of reflectarray antennas," Microwave and Optical Technology Letters, vol. 52, no. 2, pp. 364-372, Dec. 2010.

[10] W. Hu, M. Y. Ismail, R. Cahill, J. A. Encinar, V. F. Fusco, and H. S. Gamble, et al., "Electronically recon- 
figurable monopulse reflectarray antenna with liquid crystal substrate," in Second European Conference on Antennas and Propagation(EuCAP 2007), Edinburgh, 2007, pp. 1-6.

[11] S. Bildik, S. Dieter, C. Fritzsch, W. Menzel, and R. Jakoby, "Reconfigurable folded reflectarray antenna based upon liquid crystal Technology," IEEE Transactions on Antennas and Propagation, vol. 63, no. 1,

\section{김 호 겸 [서울대학교/석박tk통합과정]}

https://orcid.org/0000-0001-7196-2002

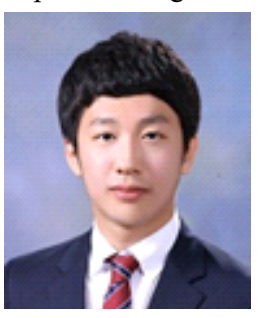

2016년 2월: 인하대학교 전기공학과 (공학 사)

2019년 2월 현재: 서울대학교 전기정보 공학부 석박통합과정

[주 관심분야] Metasurface, mmWave Antenna Array pp. 122-132, Jan. 2015.

[12] G. Perez-Palomino, M. Barba, J. A. Encinar, R. Cahill, R. Dickie, and P. Baine, et al., "Design and demonstration of an electronically scanned reflectarray antenna at $100 \mathrm{GHz}$ using multiresonant cells based on liquid crystals," IEEE Transactions on Antennas and Propagation, vol. 63, no. 8, pp. 3722-3727, Aug. 2015.

오 정 석 [서울대학교/부교수] https://orcid.org/0000-0002-2156-4927

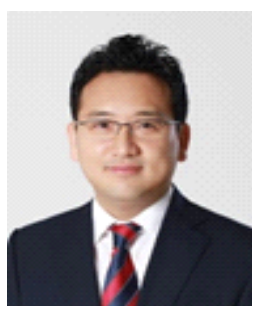

2002년 2월: 서울대학교 전기공학부 (공학 사)

2007년 2월: 서울대학교 전기공학부 (공학 석사)

2012년 8월: 미시간대학교 전기공학과 (공 학박사)

2018년 3월 현재: 서울대학교 전기정보 공학부 부교수

[주 관심분야] Antenna, Metasurface/Metamaterial, RF Circuit/ System, Wave Propagation Analysis/Modeling

\section{김 종 영 [한화시스템/연구원]}

https://orcid.org/0000-0002-3621-6802

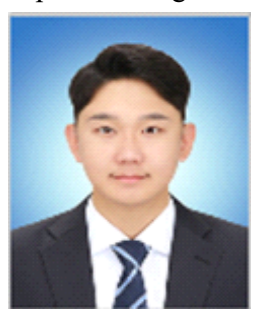

2018년 2월: 중앙대학교 전자전기공학부 (공학사)

2020년 2월: 중앙대학교 전자전기공학부 (공학석사)

2021년 현재: 한화시스템 특수레이다팀 연구원

[주 관심분야] RF, RF Sensor, Electromagnetic

Absorber, Antenna, Metasurface 